\title{
BEZZASADNOŚĆ KARANIA STOSUNKÓW KAZIRODCZYCH A KWESTIA POTOMSTWA
}

\begin{abstract}
Streszczenie. W artykule postawiona została teza, że penalizacja stosunków kazirodczych jest bezzasadna ze względu na niespójność, jaką tworzy w systemie prawa. Z jednej strony bowiem ustawodawca ma obowiązek być neutralny światopoglądowo, nie powinien zatem kształtować prawa w oparciu o jakieś osobiste lub nawet podzielane przez część społeczeństwa tabu kulturowe - a gdyby miał to robić, powinien dokonać tego także w innych przypadkach, co mogłoby doprowadzić na przykład do penalizacji zdrady małżeńskiej. Z drugiej strony - jeśli penalizacja stosunków kazirodczych ma mieć podłoże eugeniczne, to w celu zachowania spójności systemu prawa należałoby karać również stosunki między osobami ciężko chorymi na choroby genetyczne i dziedziczne, wszak one również stanowią zagrożenie dla puli genowej. W konkluzji potwierdzono tezę, że penalizacja stosunków kazirodczych - przynajmniej w kształcie zaproponowanym przez ustawodawcę obecnie, bez dostosowania reszty systemu prawa - jest nieuzasadniona.
\end{abstract}

Słowa kluczowe: kazirodztwo, tabu, eugenika, funkcje prawa, spójność systemu prawa.

\section{KAZIRODZTWO JAKO TABU KULTUROWE ORAZ JEGO PRAWNOKARNA REGULACJA W POLSCE}

W każdym środowisku i w każdej kulturze świata istnieją tematy tabu - poruszane rzadko, wywołujące niesmak i otoczone atmosferą tajemnicy oraz skandalu. Samo słowo „tabu” pochodzi z języka tongijskiego, w angielskim zaś - już jako taboo - pojawiło się po raz pierwszy w roku 1777, po odwiedzeniu przez Jamesa Cooka wyspy Tonga. Brytyjski podróżnik tak opisał jego znaczenie: „Żaden z nich nie chciał usiąść, ani spożyć choćby kawałka czegokolwiek... Gdy wyraziłem swoje zdumienie, wszyscy powołali się na taboo, jak powiedzieli: słowo, które zdaje się mieć bardzo szerokie znaczenie, ale ogółem oznacza coś zakazanego" (Cook 1793, 348; tł. własne). Jak więc wynika z samej definicji, zachowania naruszające tabu naruszają pewien zakaz i z tej racji nierzadko podlegają karze - czy to w postaci społecznego wykluczenia, czy nawet nałożonych przez aparat państwowy sankcji karnych. Choć sama treść tabu różniła się na przestrzeni wieków wśród rozmaitych środowisk, niektóre z nich były i wciąż są stosunkowo powszechne - i do takich zdają się na przykład należeć stosunki kazirodcze.

\footnotetext{
*Uniwersytet Jagielloński, Wydział Prawa i Administracji, paramaciej93@gmail.com.
} 
Polski Kodeks karny z dnia 6 czerwca 1997 r. kryminalizuje stosunki kazirodcze w artykule $201 \mathrm{w}$ następujący sposób: „Kto dopuszcza się obcowania płciowego w stosunku do wstępnego, zstępnego, przysposobionego, przysposabiającego, brata lub siostry, podlega karze pozbawienia wolności od 3 miesięcy do lat 5" (Dz.U. z 1997 r. Nr 88, poz. 553). Warto jednak zadać sobie pytanie - czy penalizacja tego zjawiska jest słuszna? Co stoi u jej podstawy? Czy pozostaje spójna z resztą założeń kodeksu karnego? Początkowo nawet samo postawienie tego pytania może wywołać oburzenie - wszak akt stosunku kazirodczego dla większości jest naturalnie odstręczający i sprzeczny z najbardziej podstawowymi instynktami. Najczęstszym uzasadnieniem penalizacji kazirodztwa wydają się względy obyczajowości i moralności publicznej, silnie powiązane z kulturowym tabu, jakim są stosunki seksualne pomiędzy osobami spokrewnionymi. Ponadto jednak powszechnie występującym w świadomości społecznej i poruszanym zarówno w debacie publicznej, jak i w rozprawach naukowych problemem jest ryzyko dotknięcia potomstwa zrodzonego z takiego aktu przez różnorakie formy chorób genetycznych i wrodzonych defektów. Niektórzy, jak Paweł Daniluk, właśnie w czynniku biologicznym upatrują głównego ratio legis dla omawianego przepisu (Daniluk, Nowak 2007-2008, 480). Oba te uzasadnienia znajdują zresztą potwierdzenie i podkreślenie w Kodeksie rodzinnym i opiekuńczym (Dz.U. z 1964 r. $\mathrm{Nr}$ 9, poz. 59), który traktuje pokrewieństwo i powinowactwo w linii prostej jako przeszkodę do zawarcia małżeństwa.

\section{FUNKCJE PRAWA ORAZ JEGO PODSTAWY AKSJOLOGICZNE W ŚWIETLE BEZSTRONNOŚCI ŚWIATOPOGLĄDOWEJ ORGANÓW WLADZY PAŃSTWOWEJ}

Należy sobie jednak zadać pytania: jakie są funkcje prawa karnego materialnego i co powinno decydować o jego treści? Wspomnianych funkcji teoria prawa zna kilka, ale z punktu widzenia obywatela, mającego styczność z prawem karnym, jedną z najistotniejszych wydaje się być funkcja ochronna. Ma ona zapewnić mu poczucie bezpieczeństwa i chronić przed krzywdą czy szkodą, której mógłby doznać ze strony innych. Jej istotę stanowi, cytując za profesorami Andrzejem Zollem i Włodzimierzem Wróblem, „,ochrona dóbr uznanych przez ustawodawcę za cenne, czy to z punktu widzenia interesów obywateli czy grup społecznych lub całego społeczeństwa, czy też z punktu widzenia całego państwa” (Wróbel, Zoll 2014, 39). W myśl funkcji ochronnej ustawodawca „zakazuje zachowań, które zmierzają do zmiany pozytywnego, z punktu widzenia aksjologicznych założeń ustawodawcy, stanu rzeczy w kierunku uznanym przez niego za szkodliwy”, nakazuje zaś zachowania, które „mają utrzymać korzystny, z punktu widzenia jego aksjologicznych założeń, stan rzeczy lub nawet które mają ten stan rzeczy zmienić w kierunku przez niego oczekiwanym” (tamże, 40). Na czym jednak oparte są owe „założenia aksjologiczne 
ustawodawcy", o których wspomniano? Na uznawanych społecznie normach moralnych? Chociaż między normami prawa karnego a normami moralnymi $z$ całą pewnością występuje stosunek krzyżowania się, to znaczy niektóre działania zabronione lub nakazane przez prawo karne są równocześnie uznawane za odpowiednio niemoralne i moralne, zdecydowanie nie można powiedzieć, by wspomnianym stosunkiem była tożsamość. Istnieją przecież takie działania, które niektórzy uznaliby za niemoralne, a jednak pozostają niekryminalizowane - jak na przykład zdrada małżeńska czy, w przypadku polskiego systemu prawnego, aborcja dokonana pod pewnymi, szczególnymi, określonymi przez ustawę warunkami. Inne ustawodawca postanowił obarczyć zagrożeniem kary, chociaż w myśl niektórych filozofii moralnych są one zjawiskiem neutralnym, a może nawet pozytywnym - tutaj za przykład posłużyć by mogło choćby zabójstwo eutanatyczne, postrzegane czasem jako przejaw szacunku dla ludzkiej wolności do samostanowienia, czy też prawo do posiadania i wykorzystywania przez osoby dorosłe niektórych substancji odurzających. Na terenie państwa jednak, w danym czasie, obowiązywać może tylko jeden system prawny, może natomiast występować wiele systemów moralnych (tamże, 42). Nawet jeśli zastosowano by zasady moralne jako bezpośrednią podstawę prawodawstwa, należałoby najpierw zapytać, które konkretnie będą to zasady, z pewnością bowiem wiele osób miałoby na ten temat własne - i odmienne od reszty - zdanie. Sama Konstytucja Rzeczypospolitej Polskiej z dnia 2 kwietnia 1997 r. zobowiązuje ustawodawcę do zachowania neutralności światopoglądowej, co wyrażono w punkcie drugim artykułu 25 tejże: „Władze publiczne w Rzeczypospolitej Polskiej zachowują bezstronność w sprawach przekonań religijnych, światopoglądowych i filozoficznych, zapewniając swobodę ich wyrażania w życiu publicznym" (Dz.U. z 1997 r. Nr 78, poz. 483 ze zm.). Wydaje się ewidentne, że opieranie przepisów prawa na zasadach którejś z wyznawanych na terenie państwa religii albo na osobistych przekonaniach pojedynczych obywateli, czy nawet ich większych grup, byłoby jasnym naruszeniem tego artykułu. Same nasze odczucia i intuicje moralne stanowią, w najlepszym wypadku, chwiejne - i bardzo subiektywne - podstawy dla prawa karnego, osobista zaś niechęć czy nawet obrzydzenie odczuwane przez niektórych w obliczu pewnych praktyk nie są wystarczającym powodem do ich kryminalizacji we współczesnym, demokratycznym państwie prawa.

Jaka zatem powinna być aksjologiczna podstawa prawa karnego? Angielski filozof John Stuart Mill w swoim eseju $O$ wolności formułuje tak zwaną harm principle - 'zasadę krzywdy', o następującym brzmieniu:

jedynym celem usprawiedliwiającym ograniczenie przez ludzkość, indywidualnie lub zbiorowo, swobody działania jakiegokolwiek człowieka jest samoobrona, że jedynym celem, dla osiągnięcia którego ma się prawo sprawować władzę nad członkiem cywilizowanej społeczności wbrew jego woli, jest zapobieżenie krzywdzie innych. Jego własne dobro, fizyczne lub moralne, nie jest wystarczającym usprawiedliwieniem. Nie można go zmusić do uczynienia 
lub zaniechania czegoś, ponieważ tak będzie dla niego lepiej, ponieważ to go uszczęśliwi, ponieważ zdaniem innych osób będzie to mądrym lub nawet słusznym postępkiem. Są to poważne powody, by go napominać, przemawiać mu do rozumu, przekonywać go lub prosić, lecz nie, by go zmuszać lub karać w razie, gdyby nas nie słuchał. Aby to ostatnie było usprawiedliwione, postępowanie, od którego chcemy go odwieść, musi zmierzać do wyrządzenia krzywdy komuś innemu. Każdy jest odpowiedzialny przed społeczeństwem jedynie za tę część swojego postępowania, która dotyczy innych. W tej części, która dotyczy wyłącznie jego samego jest absolutnie niezależny; ma suwerenną władzę nad sobą, nad swoim ciałem i umysłem (Mill 1959, 102).

Dobrowolny stosunek kazirodczy między dwiema dorosłymi osobami nie nosi znamion krzywdy dla żadnej z nich. W myśl słów Milla nie powinien podlegać ograniczeniu, z pewnością zaś nie powinien podlegać karze. Obie te jednostki bowiem, działając w ramach swojej własnej wolności, w ramach, jak pisze Mill, absolutnie suwerennej władzy nad swoim ciałem i umysłem podejmują taką decyzję. I jest ze wszech miar dozwolonym, by ją krytykować albo wypowiadać się przeciwko niej, bądź próbować odwieść od niej owe jednostki. Natomiast na gruncie zasady krzywdy nie można w tym przypadku uzasadnić użycia przymusu państwowego do ukarania takich osób.

\section{STOSUNKI KAZIRODCZE MIĘDZY DOROSEYMI JAKO PRZYKLAD „ZBRODNI BEZ OFIARY”}

Można jednak argumentować, że krzywda konkretnych osób nie powinna być jedynym czynnikiem wpływającym na reakcję karną ze strony państwa. Istnieją wszak inne dobra zasługujące na ochronę, o zakresie szerszym niż przestrzeń jednostki. Do takich zaliczyć można choćby porządek publiczny czy stabilność państwa. Nawet wtedy jednak czynnikiem uruchamiającym reakcję prawnokarną jest działanie na szkodę, czy to jednostki, czy aparatu państwowego. Innymi słowy - następuje pewnego rodzaju obiektywna zmiana stanu rzeczy na mniej korzystny. Na działaniu kryminalizowanym ktoś traci, można by rzec, że zawsze ktoś jest jego ,ofiarą”. Czy jednak na pewno zawsze tak właśnie jest w praktyce? W teorii prawa funkcjonuje termin victimless crime - 'zbrodnia bez ofiary' (Victimless Crime, n.d.). Opisuje się nim czyny, które pozostają kryminalizowane, chociaż ich jedynym uczestnikiem jest sam sprawca, bądź następują one między dwiema dorosłymi osobami, które złożyły odpowiednie oświadczenie woli. Można do nich zaliczyć na przykład niespotykane zachowania seksualne czy użytkowanie silnych środków odurzających. Stosunki kazirodcze są ewidentnym przykładem takiej właśnie ,zbrodni bez ofiary”. Ich kryminalizowanie wydaje się bezcelowe, nie prowadzą bowiem do obiektywnego pogorszenia sytuacji ani samych zaangażowanych osób, ani aparatu państwa jako takiego. Jeśli cokolwiek ulega naruszeniu w sytuacji dobrowolnego 
stosunku kazirodczego między dorosłymi, to mogą być to, co najwyżej, przekonania światopoglądowe poszczególnych jednostek - po pierwsze jednakże, gdyby owe przekonania były dobrem powszechnie chronionym prawnie, szybko okazałoby się, że większość czynności czy rzeczy stałaby się zakazana. Z całą pewnością bowiem gdzieś można by znaleźć osobę, którą, ze względu na jej światopogląd, oburza ich występowanie. Po drugie jednak nawet obrona cudzych uczuć nie może być realizowana poprzez ograniczanie praw innej osoby. Same intuicje moralne czy przekonania, dotyczące słuszności tych czynów, nie są, jak wspomniano, odpowiednią podstawą dla norm prawa karnego. W świetle zarówno zasady krzywdy, jak i koncepcji zbrodni bez ofiary kryminalizacja dobrowolnych stosunków kazirodczych między dorosłymi jest w oczywisty sposób bezzasadna.

\section{ZNACZENIE KWESTII ZDROWIA POTOMSTWA DLA DYSKUSJI O STOSUNKACH KAZIRODCZYCH}

W opozycji można jednak wysunąć argument, o którym wspomniano już na początku artykułu - w razie gdyby, w konsekwencji stosunku kazirodczego, doszło do spłodzenia potomstwa, dziecko poczęte w taki sposób obarczone jest zwiększonym ryzykiem chorób genetycznych i wrodzonych defektów. Jeśli tak by się stało, stosunek ten stanowiłby widoczne naruszenie zasady krzywdy Milla, a także koncepcji zbrodni bez ofiary - sytuacja niepełnosprawnego dziecka zostałaby bowiem w obiektywny sposób pogorszona i z pewnością można by stwierdzić, iż wyrządzono mu krzywdę wbrew jego woli. Dziecko nie miało przecież, z oczywistych powodów, możliwości wyrażenia zgody na akt swojego własnego poczęcia. Jest to niewątpliwie celna uwaga, która wymaga głębszego rozważenia.

Powstałe początkowo na gruncie common law i przeniesione później na grunt prawa kontynentalnego koncepcje skarg z tytułu wrongful birth i wrongful life wskazują, że istotnie fakt urodzenia się w stanie niepełnosprawności uznany może być za krzywdę uprawniającą do zadośćuczynienia. Wrongful birth, skarga z tytułu „złego urodzenia”, stanowi powództwo z powodu zaniechanych lub źle wykonanych przez pozwanego badań prenatalnych albo z powodu nieudzielenia informacji, które pozwoliłyby rodzicom uniknąć poczęcia i w konsekwencji zapobiec urodzeniu się dziecka z ciężkimi wrodzonymi wadami lub chorobami genetycznymi (Nesterowicz 2011, 358-365). Skarga z tytułu wrongful life, „złego życia", stanowi roszczenie podobne, podnoszone jednak nie przez rodziców, a przez samo niepełnosprawne dziecko w związku z krzywdą, której doznało, rodząc się jako osoba niepełnosprawna lub obarczona jakimiś schorzeniami. W obu typach spraw chodzi wyłącznie o te zawinione działania pozwanego, których efektem było przyjście dziecka na świat, nie zaś spowodowanie jego choroby 
- za to odpowiadają bowiem odrębne przepisy (Justyński 2003, 19). Jak widać zatem, jeśli urodzenie się dziecka niepełnosprawnego może być uznane za wyrządzoną mu krzywdę, można - całkowicie rozsądnie - stwierdzić, że, na podstawie wspomnianych wyżej podstaw aksjologicznych, również takie urodzenie powinno być penalizowane, a co za tym idzie, penalizowane mogłyby być także czynności zmierzające do poczęcia lub je umożliwiające, tak jak ma to miejsce w obecnych przepisach kodeksu karnego.

Nawet jednak w świetle powyższego argumentu eugenicznego, któremu można przypisać pewną wartość, obecnym regulacjom brakuje spójności. Kryminalizują one bowiem, oprócz stosunków między osobami biologicznie spokrewnionymi, także stosunki z osobą przysposobioną bądź przysposabiającą. Brak tutaj faktycznego pokrewieństwa, a co za tym idzie - nie występuje zwiększone ryzyko powikłań dla zdrowia płodu, a w każdym razie nie jest ono większe niż w przypadku stosunku z dowolną inną osobą. Jest to więc, w oczywisty sposób, zakaz podyktowany względami kulturowymi oraz obyczajowymi - wizja współżycia między osobami o takiej, a nie innej więzi z dużym prawdopodobieństwem jest dla wielu odstręczająca. Ponownie jednak, nawet jeśli tak jest - nie jest to wystarczająca ani odpowiednia podstawa do ograniczania czyichkolwiek praw, a tym bardziej do karania takich zachowań. Każdy człowiek posiada własny światopogląd i własne przekonania oraz własny próg wrażliwości, a co za tym idzie, każdy człowiek odpowiedziałby inaczej na pytania dotyczące tego, z jakimi zachowaniami czuje się niekomfortowo albo jakie uznaje za niemoralne. Kierowanie się intuicjami moralnymi poszczególnych osób uwikłałoby ustawodawcę w pułapkę, z której nie ma ucieczki. Z pewnością bowiem wielu ludzi, w szczególności tych gorliwie wyznających jakąś religię, mogłoby podać długą listę innych czynności - seksualnych i nie tylko - które są w ich oczach nieczyste, grzeszne i zasługujące na karę, jak na przykład stosunki seksualne utrzymywane przed zawarciem małżeństwa, spożywanie alkoholu lub niektórych pokarmów, a nawet przyjmowanie krwi w czasie transfuzji. Warto wspomnieć także o jednej, niezwykle istotnej rzeczy - normy moralne nie tylko występują w wielu różnych odmianach, ale ulegają zmianom w czasie, nierzadko drastycznym i głębokim. W większości krajów świata stosunki homoseksualne były penalizowane w jakimś okresie historycznym - dotyczy to także Polski, a w każdym razie ziem polskich, gdzie w latach 1832-1935 obowiązywały ustawy karne zaborców. W kodeksie karnym z 1932 roku przestano je kryminalizować. Czy wynikało to z jakichś głębokich, drastycznych przemian społecznych i zmiany stosunku przeciętnego obywatela do osób homoseksualnych? Jest to cokolwiek wątpliwe - bardzo długo pociąg wobec osób tej samej płci był tematem tabu, a jeszcze w 2013 roku na pytanie: „Czy homoseksualizm powinien być akceptowany przez społeczeństwo?” odpowiedziała twierdząco zaledwie około połowa Polaków (The Global Divide on Homosexuality 2013). Prawdopodobnie więc rezygnacja z karania aktów 
seksualnych osób tej samej płci nie wynikała wcale z jakiejś cudownej, nowo nabytej tolerancji, ale po prostu z pragmatycznego - i ze wszech miar rozsądnego - przekonania, że cokolwiek dwóch dorosłych ludzi robi z własnej woli we własnej sypialni, nie jest to sprawą państwa - choćby nawet było odstręczające dla przeciętnego obywatela czy grzeszne dla kapłanów. Z takim rozumieniem sprawy trudno się nie zgodzić. Pluralizm wartości jest bowiem jednym z koniecznych elementów współczesnego, demokratycznego państwa prawa - jako jego obywatele musimy przystać na to, że nie wszystko, co robią inni, będzie nam się podobało i nie wszystko będziemy w stanie pochwalić, ale póki owe praktyki nie ingerują w prawa innej osoby, winniśmy je tolerować, choćby nawet z powodu świadomości, że dokładnie ta zasada może chronić nas samych przed karą za czynności, które inni mogliby uznać za godne penalizowania na gruncie wyznawanych przez nich norm moralnych.

\section{AKSJOLOGICZNE ROZDROŻA - KONIECZNOŚĆ WYBORU MIĘDZY PRYMATEM OSOBISTEJ WOLNOŚCI REPRODUKCYJNEJ A OCHRONĄ JAKOŚCI ŻYCIA POPULACJI JAKO OGÓŁU}

W tym momencie stajemy jednak na rozdrożu. Przedstawiono, dlaczego stosowanie norm moralnych, wyznawanych przez różne osoby lub grupy w charakterze bezpośredniej podstawy przepisów prawa, jest raczej niefortunnym i bardzo trudnym w faktycznej realizacji pomysłem. Gdyby więc chciano utrzymać zakaz stosunków kazirodczych, nawet wyłączając z niego współżycie z osobą przysposobioną czy przysposabiającą, jako ratio legis pozostałby ustawodawcy jedynie argument eugeniczny.

Jeśli jednak uznamy, że czyny, stwarzające zagrożenie poczęcia dziecka obarczonego znacznie zwiększonym ryzykiem wrodzonych defektów i chorób genetycznych, powinny być kryminalizowane, kryminalizacja ta nie mogłaby się bynajmniej ograniczyć do samych stosunków kazirodczych. Istnieje wszakże wiele innych czynników mogących istotnie zwiększyć zagrożenie dla zdrowia płodu. Współczesne badania naukowe dowodzą na przykład wyraźnego istnienia korelacji między wiekiem rodziców a istotnie zwiększonym ryzykiem dla zdrowia ich dzieci (Olshan, Schnitzer, Baird 1994, 80-84; Morris, Mutton, Alberman 2002). Dużo bardziej oczywistym dla laika przypadkiem jest jednak chociażby przykład dzieci osób, które same cierpią na jakiegoś rodzaju genetyczne schorzenia czy defekty, jak zespół Downa. Potomstwo takich osób ma niezwykle dużą szansę, a czasem rzeczywistą pewność odziedziczenia po swych rodzicach przynajmniej części z ich problemów zdrowotnych. Jeśli więc uzasadni się kryminalizację stosunków kazirodczych ryzykiem dla zdrowia potencjalnego potomstwa, logiczną konsekwencją tejże decyzji będzie także ograniczenie lub zakazanie dobrowolnych stosunków między dorosłymi osobami w innych przypadkach, takich jak 
wskazane powyżej, co z kolei skutkuje bezpośrednio realizowaniem polityki eugeniki negatywnej.

Można postulować, że jest to korzystne - $\mathrm{i}$ istotnie, wysuwano w historii podobne postulaty, a szczególny rozgłos uzyskały one na początku XX w., u zarania ruchów eugenicznych. Twierdzono między innymi, że tego typu działania oczyszczają pulę genową populacji i prowadzą do zwiększenia liczby zdrowych osobników w społeczeństwie, a co za tym idzie - ostatecznie do poprawy kondycji gatunku ludzkiego (Musielak 2008). Późniejsze powstanie nazistowskiej Trzeciej Rzeszy oraz jej okrutne praktyki i eksperymenty, mające w zamyśle stworzenie idealnej, ,,czystej” rasy aryjskiej, doprowadziły do zdyskredytowania pojęcia eugeniki i na zawsze powiązały ten termin w świadomości powszechnej z ludzkim bestialstwem i nauką w służbie zbrodniczego państwa.

Pytanie, które należy sobie postawić, brzmi - czy na pewno chcemy wracać akurat do tej przeszłości? Nie można zaprzeczyć, że istnieją pewne argumenty przemawiające na korzyść eugeniki i że poruszane przez nią kwestie nie są całkowicie antynaukowe - niezależnie od tego jednak wydaje się ona być fundamentalnie sprzeczna z zasadami współczesnego demokratycznego państwa prawa. Uderza w podstawowe wolności człowieka, w jego prawo do wyrażania własnej seksualności, do samostanowienia i decydowania o swoich działaniach. Dzieli ludzi na klasy - na tych, którzy zostali uznani za wystarczająco wartościowych, by zyskać prawo do rozmnażania się i na tych, którym takie prawo odebrano, degradując ich do roli czegoś pośledniejszego niż pełnoprawna istota ludzka. Jeśli zaś mielibyśmy poprzestać wyłącznie na karaniu związków kazirodczych, pozostawiając inne opisywane przypadki niekryminalizowane - byłby to przykład rażącej niespójności systemu prawnego.

Osobisty niesmak, a nawet obrzydzenie związane ze stosunkami kazirodczymi są reakcjami w pełni zrozumiałymi - w żaden sposób nie uzasadniają jednak ani zakazu, ani tym bardziej karania takich stosunków, emocje same w sobie nie powinny być bowiem podstawą dla żadnej formy prawodawstwa. Ostatecznie, dopóki stosunki te pozostają w sferze dobrowolnego kontaktu dwóch dorosłych osób zdolnych do swobodnego wyrażenia swojej woli, nie powinny stanowić obiektu zainteresowania państwa. Są przecież - w pewien bardzo kuriozalny sposób - wyrazem miłości, nawet jeśli jest to miłość społecznie nieakceptowana. Jeśli zaś miałyby doprowadzić do przyjścia na świat osoby niepełnosprawnej i cierpiącej, odpowiedzialność za to spoczywa na rodzicach, ale jest ona co najwyżej odpowiedzialnością moralną. Gdyby miano ukarać takich kochanków, to samo trzeba by uczynić ze wszystkimi innymi, którzy świadomie decydują się na potomstwo w sytuacji, w której może się ono urodzić obciążone chorobą czy niepełnosprawnością. Czasy spartiatów porzucających swe kalekie dzieci w leśnych ostępach dawno już minęły, jeśli więc pozwalamy dziedzicznie chorym płodzić i wychowywać dzieci, identyczne prawo winni jesteśmy krewnym decydującym się na potomstwo, niezależnie od emocji, jakie to w nas wywołuje. Któż może zresztą 
powiedzieć, że takie dziecko - choćby i nawet urodziło się niepełnosprawne - nie może, dzięki postępującemu rozwojowi medycyny i miłości oraz trosce swoich rodziców, prowadzić wartościowego, radosnego życia i stać się pełnoprawnym, ważnym członkiem społeczeństwa?

Wywód pozwolę sobie zakończyć słowami Bertranda Russella, które, co prawda, omawianej kwestii nie rozstrzygają - wskazują jednak wyraźnie, że jest ona mniej oczywista, niż może się wydawać na pierwszy rzut oka i zasługuje na dyskusję. Filozof zdaje się też przy ich pomocy zwracać uwagę na fakt, że emocje i emocjonalne reakcje nie są dobrym doradcą w kwestii stanowienia o tym, co powinno być dozwolone, a co nie. „Przypuśćmy, że bomby atomowe zredukowały ludzką populację do jednego brata i jednej siostry - czy powinni oni po prostu pozwolić gatunkowi ludzkiemu na wymarcie? Nie znam odpowiedzi, ale nie uważam, że może być twierdząca tylko na podstawie tego, że kazirodztwo jest haniebne" (Russell 2009, 47).

\section{BIBLIOGRAFIA}

Cook, James, James King. 1793. A voyage to the Pacific Ocean... Vol. 3. London: Printed for Champante and Whitrow, Jewry Street, Aldgate, and M. Watson, Hermitage-Bridge. https://play. google.com/books/reader?id=F0M-AAAAYAAJ\&hl=pl\&printsec=frontcover\&pg=GBS.PA1 [dostęp 16.06.2018].

Daniluk, Paweł, Celina Nowak. 2007-2008. „Kazirodztwo jako problem karnoprawny (dwugłos)”. Archiwum Kryminologii 29-30: 473-487.

Justyński, Tomasz. 2003. Poczęcie i urodzenie się dziecka jako źródło odpowiedzialności cywilnej. Kraków: Kantor Wydawniczy Zakamycze.

Mill, John Stewart. 1959. „O wolności”. Tł. Amelia Kurlandzka. W Utylitaryzm. O wolności. Tł. Maria Ossowska, Amelia Kurlandzka. Wstęp Tadeusz Kotarbiński. 92-227. Warszawa: Państwowe Wydawnictwo Naukowe.

Morris, Joan K., David E. Mutton, Eva Alberman. 2002. „Revised estimates of the maternal age specific live birth prevalence of Down's syndrome”. Journal of Medical Screening 9: 2-6.

Musielak, Michał. 2008. Sterylizacja ludzi ze względów eugenicznych w Stanach Zjednoczonych, Niemczech $i$ w Polsce (1899-1945). Wybrane problemy. Poznań: Wydawnictwo Poznańskie.

Nesterowicz, Mirosław. 2011. „Roszczenia z tytułu wrongful conception, wrongful birth, wrongful life". W Prawo medyczne. Komentarze i glosy do orzeczeń sadowych. 422-459. Warszawa: LexisNexis.

Olshan, Andrew F., Patricia G. Schnitzer, Patricia A. Baird. 1994. „Paternal age and the risk of congenital heart defects". Teratology 50 (1): 80-84.

Russell, Bertrand. 2009. Human Society in Ethics and Politics. London: Routledge.

The Global Divide on Homosexuality [Ankieta dotycząca stosunku do homoseksualizmu]. 2013. http://www.pewglobal.org/files/2013/06/Pew-Global-Attitudes-Homosexuality-ReportFINAL-JUNE-4 2013.pdf [dostęp 28.02.2018].

„Victimless Crime”. W Encyclopedia of Crime and Justice. https://www.encyclopedia.com/socialsciences-and-law/law/law/victimless-crime\#1-1G2:3403000270-full [dostęp 28.02.2018].

Wróbel, Włodzimierz, Andrzej Zoll. 2014. Polskie prawo karne. Część ogólna. Kraków: Społeczny Instytut Wydawniczy Znak. 
Maciej Para

\title{
ILLEGITIMACY OF PENALIZING INCESTUOUS RELATIONS AND THE OFFSPRING ISSUE
}

\begin{abstract}
The paper proposes a thesis that penalization of incestuous relations is illegitimate on the grounds of inconsistency it creates in the legal system. On one hand, the legislator has to be neutral in its worldview and therefore should not create laws based on its own or even shared by some people cultural taboos - and if it were to, it should do it also in other cases, which may lead to penalizing, for example, cases of adultery in marriage. On the other hand - if the base of penalizing incestuous relations is a eugenic one, then in order to maintain coherency of the legal system, relations between people suffering from severe genetic and inherited diseases should also be penalized. After all, they also pose a danger to the gene pool. Thus, it should be stated that penalizing incestuous relationships - at least in the way currently proposed, without adjusting the other legal system is illegitimate.
\end{abstract}

Keywords: incest, taboo, eugenics, the functions of law, coherency of the legal system. 